\title{
Morphogenic, structural, and productive characteristics of Cenchrus ciliaris L. grown using different levels of caprine and ovine biofertilizer
}

\section{Características morfogênicas, estruturais e produtivas de Cenchrus ciliaris $\mathrm{L}$. sob diferentes níveis de biofertilizante caprino e ovino}

\author{
Jennifer Figueiredo da Silva'; Alan da Cunha Honorato²; \\ Mário Adriano Ávila Queiroz ${ }^{3}$; Mateus Matiuzzi da Costa ${ }^{3}$; \\ Adriana Mayumi Yano-Melo ${ }^{4 *}$
}

\begin{abstract}
The aim of this study was to evaluate the morphogenic, structural, and productive characteristics of Cenchrus ciliaris L. in response to different doses of biofertilizers that originate from the anaerobic biodigestion of goat and sheep fecal matter on Yellow Argisoil. The experiment was performed in a greenhouse, in a completely randomized factorial design using two types of biofertilizers and five dosages $(0 \%, 2.5 \%, 5.0 \%, 7.5 \%$, and $10 \%$ of soil volume), with four repeats, for the duration of two vegetative cycles. In the first cycle, there was an increase in leaf lifespan and leaf/stem ratio with the use of $10 \%$ and $7.5 \%$ caprine biofertilizer, respectively. From the second cycle, doses of biofertilizers between $7.5 \%$ and $10 \%$ led to an improvement in the development of the morphogenic variables leaf sprouting rate, leaf and pseudostem elongation rate, leaf lifespan, and senescence, as well as the structural characteristics - expanded leaf length and width, number of sprouting, expanded and live leaves, and expanded/expanding leaf ratio, resulting in a $73 \%$ increase in biomass. It was concluded that the use of biofertilizers improves the main morphogenic and structural characteristics of Cenchrus ciliaris L., resulting in increased fodder mass yield.
\end{abstract}

Key words: Caprine. Ovine. Excreta. Buffel Grass.

\section{Resumo}

O objetivo neste trabalho foi avaliar as características morfogênicas, estruturais e produtivas de Cenchrus ciliaris L., frente a diferentes doses de biofertilizantes, oriundos da biodigestão anaeróbica de fezes de caprinos e ovinos em Argissolo Amarelo. O experimento realizado em casa de vegetação foi conduzido em delineamento inteiramente casualizado em arranjo fatorial utilizando-se dois tipos de biofertilizantes e cinco doses $(0 ; 2,5 ; 5,0 ; 7,5$ e $10 \%$ do volume do solo), em quatro repetições, por dois ciclos vegetativos. No $1^{\circ}$ ciclo, com aplicação de $10 \%$ e 7,5\% de BC houve incremento na duração de

\footnotetext{
${ }^{1}$ Discente, Programa de Pós-Graduação em Ciência Animal, Universidade Federal do Vale do São Francisco, UNIVASF, Petrolina, PE, Brasil. E-mail: figueiredo_jennifer@hotmail.com

2 Discente, Pós-Graduação em Agronomia-Produção Vegetal, UNIVASF, Petrolina, PE, Brasil. E-mail: alan_honorato18@ hotmail.com

3 Profs., Programa de Pós-Graduação em Ciência Animal, UNIVASF, Petrolina, PE, Brasil. E-mail: mario.queiroz@univasf.edu. br; mateus.costa@univasf.edu.br

${ }^{4}$ Profa, Programas de Pós-Graduação em Agronomia-Produção Vegetal, CPGA-PV e em Ciência Animal CPGCA, UNIVASF, Petrolina, PE, Brasil, E-mail: amymelo17@hotmail.com

* Author for correspondence
} 
vida da folha e na relação folha/colmo, respectivamente. A partir do $2^{\circ}$ ciclo, doses entre 7,5 a $10 \%$ de ambos os biofertilizantes proporcionaram melhoria no desenvolvimento das variáveis morfogênicas taxa de aparecimento e alongamento foliar e do pseudocolmo, duração de vida da folha e senescência; e características estruturais -largura e comprimento da folha expandida, número de folhas emergentes, expandidas e vivas e relação folha expandida/folha em expansão, com consequente incremento de $73 \%$ na biomassa. Conclui-se que os biofertilizantes incrementam as principais características morfogênicas e estruturais de Cenchrus ciliaris L., resultando na elevação da produção de massa de forragem.

Palavras-chave: Caprinos. Ovinos. Dejetos. Capim Buffel.

\section{Introduction}

The livestock production system in Brazil is based mainly on pasture grazing, placing the country in a prominent position in the beef cattle production industry, and making investments in goat and sheep production more attractive (EGLER et al., 2013).

The northeast region of Brazil contributes greatly to sheep and goat farming, since more than half of the national livestock is found there (IBGE, 2012), with pastures being the main food source for animal production.

Among the forage species, buffel grass (Cenchrus ciliaris L.) is one of the Gramineae (= Poaceae) species recommended for cultivated pastures, and is considered as the plant best adapted to semi-arid conditions. A key characteristic underpinning its resilience regarding water deficiency is its efficient use of water (NAWAZISH; HAMEED, 2006).

Forage availability has an essential role in terms of both the reasonable use of pastures, as well as the individual performance of the animal and/or gain per area, whereby the morphogenic and structural characteristics of the forage sward indicate the degree of development of the grass. Nutritional, environmental, and cultivation factors determine the production outcomes of the grass, in particular regarding fertilization, which is a cultivation strategy that significantly alters forage productivity (PEREIRA, 2013).

Bio fertilizers that originate from anaerobic digestion have become an alternative use of the generated excreta, as it is estimated that each adult goat produces $600 \mathrm{~kg}$ of excreta per year, and recycling of this excreta is highly desirable from the economic and environmental viewpoints. In addition, nearly all macro and micronutrients required for plant nutrition are found in bio fertilizers, and improve the soil biological and microbiological quality, thus enhancing organic matter decomposition and playing an essential role in nutrient dynamics in various ecosystems (LOURENTE, 2011, SILVA et al., 2015).

Thus, the aim of this study was to evaluate the morphogenic, structural, and productive characteristics of Cenchrus ciliaris, in response to different doses of biofertilizers that originate from the anaerobic digestion of goat and sheep fecal matter in Yellow Argisoil.

\section{Material and Methods}

The experiment was performed in a greenhouse, between January and April 2014. The soil utilized was classified as typical dystrophic Yellow Argisoil, with a medium/sandy texture, presenting the following chemical characteristics: $0.04 \mathrm{~g} \mathrm{~kg}^{-1} \mathrm{P}$, $0.06 \mathrm{~g} \mathrm{~kg}^{-1} \mathrm{~K}, 0.68 \mathrm{~g} \mathrm{~kg}^{-1} \mathrm{Ca}, 0.12 \mathrm{~g} \mathrm{~kg}^{-1} \mathrm{Mg}, 3.28$ $\mathrm{mg} \mathrm{kg}{ }^{-1} \mathrm{Cu}, 14.46 \mathrm{mg} \mathrm{kg}^{-1} \mathrm{Fe}, 11.94 \mathrm{mg} \mathrm{kg}^{-1} \mathrm{Mn}$, $4.40 \mathrm{mg} \mathrm{kg}^{-1} \mathrm{Zn}, 2.5 \mathrm{~g} \mathrm{~kg}^{-1} \mathrm{OM}$ and $\mathrm{pH} 8.59$.

Seeds of Cenchrus ciliaris var. biloela were previously treated to break their dormancy. They were exposed to a temperature of $5{ }^{\circ} \mathrm{C}$ for a period of 7 days, followed by $15 \mathrm{~h}$ in a water bath at 53 ${ }^{\circ} \mathrm{C}$, and subsequent addition of potassium nitrate solution at $2 \%$.

Fifty seeds were sown in each 5-L pots, and excess sprouts were removed such that three plants remained that constituted one experimental unit. 
The plants were irrigated daily in order to maintain $80 \%$ of the soil's field capacity.

Two types of biofertilizer were previously produced from the waste of goats (CB - caprine biofertilizer) and sheep (OB - ovine biofertilizer) of no defined breed, in a 50:50\% volume: concentrate diet based on elephant grass (Pennisetum purpureum Schumach.) silage and a concentrate of corn, soybean forage, and minerals. After a period of 30 days of adaptation to the diet, the substrates for the $10-\mathrm{L}$ bench biodigesters were prepared, consisting of 750 $\mathrm{g}$ of feces dried at $55^{\circ} \mathrm{C}$ for $72 \mathrm{~h}$ in a drying oven with circulation and air exchange, $550 \mathrm{~g}$ of inoculum in natura produced from bovine fresh feces and rumen fluid, all diluted in 7.9 L of peptone water, resulting in a level of total solids of approximately $4 \%$. The biodigestors remained in activity for 70 days in order to reduce the microbial load of the feces, accompanied by daily gas production; following this activity period, the biofertilizers were obtained and used. They were stored in a freezer at temperatures between -10 and $-15{ }^{\circ} \mathrm{C}$, for a period of 20 days before their first application.

The following concentrations of biofertilizers were used: $0 \%$ (control), 2.5\%, 5.0\%, 7.5\%, and $10 \%$ in a volume of $3.0 \mathrm{~kg}$ of soil. These doses were divided into four weekly applications $\left(1^{\text {st }}, 7^{\text {th }}, 14^{\text {th }}\right.$, and $21^{\text {st }}$ days of the experiment), and the procedure was repeated during the second vegetative cycle

Soil samples from each experimental unit were collected during two periods: a) at the end of the first vegetative cycle and b) at the end of the second vegetative cycle; their chemical characteristics are described in Table 1.

Table 1. Chemical characteristics of soils cultivated with the addition of five doses $(0 \%, 2.5 \%, 5.0 \%, 7.5 \%$, and $10 \%$ of soil volume) of two biofertilizers (derived from goat and sheep feces).

\begin{tabular}{|c|c|c|c|c|c|c|c|c|c|c|c|c|}
\hline \multirow[t]{2}{*}{ Dose } & Cycle & $\mathbf{N}$ & $\mathbf{P}$ & $\mathbf{K}$ & $\mathbf{C a}$ & Mg & $\mathbf{S}$ & $\mathbf{B}$ & $\mathbf{C u}$ & $\mathrm{Fe}$ & Mn & $\mathbf{Z n}$ \\
\hline & & & & -g I & & & & & & $\mathrm{mg} \mathrm{Kg}^{-1}$ & & \\
\hline \multicolumn{13}{|c|}{ Ovine Biofertilizers - OB } \\
\hline \multirow{2}{*}{$0 \%$} & $1^{\mathrm{st}}$ & 15.04 & 2.47 & 14.25 & 3.36 & 2.47 & 1.43 & 4.57 & 5.21 & 155.25 & 28.75 & 14.55 \\
\hline & $2^{\text {nd }}$ & 9.63 & 3.72 & 19.75 & 5.14 & 2.68 & 1.46 & 12.90 & 4.51 & 90.50 & 42.25 & 16.04 \\
\hline \multirow{2}{*}{$2.5 \%$} & $1^{\text {st }}$ & 13.62 & 2.91 & 25.25 & 3.25 & 2.17 & 1.49 & 3.79 & 4.52 & 326.95 & 36.00 & 14.17 \\
\hline & $2^{\text {nd }}$ & 10.14 & 5.09 & 23.00 & 4.38 & 2.21 & 1.02 & 3.30 & 3.45 & 96.66 & 28.25 & 14.24 \\
\hline \multirow{2}{*}{$5 \%$} & $1 \mathrm{st}$ & 17.19 & 2.72 & 28.75 & 3.17 & 2.06 & 1.64 & 4.09 & 8.13 & 214.90 & 38.50 & 19.63 \\
\hline & $2^{\text {nd }}$ & 11.33 & 4.37 & 37.75 & 3.93 & 2.06 & 1.25 & 4.38 & 4.83 & 106.76 & 36.50 & 16.68 \\
\hline \multirow{2}{*}{$7.5 \%$} & $1^{\mathrm{st}}$ & 14.26 & 2.84 & 33.25 & 2.97 & 1.68 & 1.37 & 4.53 & 4.17 & 162.46 & 32.25 & 17.03 \\
\hline & $2^{\text {nd }}$ & 11.95 & 3.74 & 25.37 & 3.64 & 2.04 & 0.47 & 7.77 & 5.18 & 138.39 & 21.50 & 18.96 \\
\hline \multirow{2}{*}{$10 \%$} & $1^{\mathrm{st}}$ & 15.74 & 2.34 & 37.50 & 3.44 & 2.02 & 1.70 & 4.97 & 5.19 & 168.88 & 33.50 & 23.23 \\
\hline & $2^{\text {nd }}$ & 13.10 & 4.06 & 39.12 & 3.44 & 1.94 & 1.11 & 8.51 & 4.65 & 85.52 & 19.00 & 19.25 \\
\hline \multicolumn{13}{|c|}{ Caprine Biofertilizers - CB } \\
\hline \multirow{2}{*}{$0 \%$} & $1^{\text {st }}$ & 11.33 & 1.69 & 31.12 & 3.78 & 2.60 & 1.53 & 5.34 & 3.69 & 137.56 & 33.5 & 14.44 \\
\hline & $2^{\text {nd }}$ & 9.75 & 3.83 & 18.62 & 5.01 & 2.83 & 0.82 & 7.50 & 4.70 & 79.33 & 32.25 & 13.87 \\
\hline \multirow{2}{*}{$2.5 \%$} & $1^{\text {st }}$ & 14.94 & 1.75 & 36.75 & 3.61 & 2.47 & 1.55 & 5.54 & 4.59 & 120.78 & 32.25 & 17.50 \\
\hline & $2^{\text {nd }}$ & 10.92 & 2.95 & 31.25 & 3.94 & 2.27 & 1.22 & 7.53 & 6.54 & 88.81 & 21.08 & 11.17 \\
\hline \multirow{2}{*}{$5 \%$} & $1^{\text {st }}$ & 15.04 & 2.22 & 37.37 & 3.21 & 2.08 & 1.36 & 4.99 & 5.74 & 128.37 & 109.25 & 18.09 \\
\hline & $2^{\text {nd }}$ & 11.50 & 3.25 & 41.87 & 3.60 & 2.01 & 1.38 & 6.86 & 6.39 & 55.07 & 20.42 & 12.51 \\
\hline \multirow{2}{*}{$7.5 \%$} & $1^{\mathrm{st}}$ & 21.70 & 2.92 & 26.5 & 3.45 & 1.94 & 1.55 & 6.72 & 6.66 & 94.47 & 34.00 & 18.79 \\
\hline & $2^{\text {nd }}$ & 13.88 & 3.95 & 43.25 & 3.50 & 2.12 & 1.72 & 7.85 & 8.06 & 79.32 & 23.67 & 17.31 \\
\hline \multirow{2}{*}{$10 \%$} & $1^{\mathrm{st}}$ & 15.85 & 2.52 & 30.01 & 3.41 & 2.17 & 1.53 & 5.23 & 5.57 & 161.76 & 41.55 & 17.59 \\
\hline & $2^{\text {nd }}$ & 15.55 & 4.42 & 26.37 & 3.13 & 1.91 & 1.54 & 7.62 & 6.23 & 60.54 & 21.30 & 15.21 \\
\hline
\end{tabular}


In order to evaluate the parameters of vegetative development, the following structural and morphogenic assessments were performed on Cenchrus ciliaris plants 10 days after seed germination, at three-day intervals in each cycle: plant (Hp) and stem height (Hs), length (FBL) and width (FBW) of the foliar blade (cm). From these variables, the following rates were determined: leaf elongation (LER), leaf sprouting (LSR), pseudostem elongation (PsER), senescence (SnR), and height (HR), as well as total leaf lifespan (LLt), leaf expansion lifespan (LL-exps), and expanded leaf lifespan (LL-Expd). Length of the expanded leaf (LLgt-Expd), length of leaf in expansion (LLgt-Exps), width of the expanded leaf (LW-Expd) and width of leaf in expansion (LWExps), number of emerging (NLEmerg), expanded (NLExpd), in expansion (NLExps), and live (NLL) leaves, expanded/expanding leaf ratio (LExpd/ LExps) and leaf/stem ratio (L/S), and finally biomass, were also determined.

The following measurements were taken using a millimeter ruler: Hp- measured between the base of the plant and the curvature of the last leaf, Hsmeasured between the base of the stem and the base of the last leaf produced, FBL- measured from the ligule to the apex of the leaf, and FBW-measured between the two extremities of the leaf.

The variables analyzed were then calculated as follows: LSR leaf/tiller/day was obtained by dividing the number of leaves produced per tiller during the evaluation period; LER ( $\mathrm{mm} /$ leaf/day) was calculated from the difference between the final length of the leaf and the length of the leaf at the start of the evaluation, divided by the number of days of growth; PsER (mm/day), obtained from the difference between the final and initial length of the stem, divided by the number of days evaluated; LLt (days), estimated taking into account the time between the appearance of the leaf apex and the start of senescence; LL-Exps measured from the time between the appearance of leaves and the end of the evaluations; SnR (mm/day/ tiller), calculated by dividing the final length of the senescent tissue by the number of days involved. A leaf was considered senescent when more than $50 \%$ of a leaf was compromised due to the senescence process. LLgt-Expd $(\mathrm{cm})$ and LLgt-Exps $(\mathrm{cm})$, as well as LW-Expd $(\mathrm{cm})$ and LW-Exps $(\mathrm{cm})$ were obtained from the mean length and width of those leaves during the evaluation period, respectively; NLEmerg (leaves/tiller), NLExpd (leaves/tiller), NLExps (leaves/tiller) and NLL (leaves/tiller) were obtained by adding all the leaves produced, and that remained expanded, in expansion, and alive by the end of the evaluation, respectively; LExpd/LExps ratio was obtained by dividing NLL by NLExps and the $\mathrm{L} / \mathrm{S}$ ratio by dividing the NLL by the PsER.

In order to determine the biomass production, in each experimental unit, the grass was cut $10 \mathrm{~cm}$ above the soil level at the end of each cycle, and weighed before (fresh biomass) and after being dried in a drying oven with circulation and air exchange at $55^{\circ} \mathrm{C}$ for $72 \mathrm{~h}$ (dry biomass).

The evaluations were terminated immediately after $30 \%$ of the plants presented with an inflorescence (around 25 days), corresponding to a condition of balance between the production of dry matter and the nutritional quality (NABINGER, 1996). The evaluation was then repeated for another cycle, with a 13-day interval between the $1^{\text {st }}$ and $2^{\text {nd }}$ cycles.

The experiment was conducted in a completely randomized factorial design $(2 \times 5)$ using two types of biofertilizer (ovine and caprine) $\times$ five doses of biofertilizer $(0 \%, 2.5 \%, 5.0 \%, 7.5 \%$, and $10 \%)$ with four replicates. All the result variables were analyzed separately in two distinct, consecutive, vegetative cycles.

In the study of morphogenesis and structural characteristics, the variables were submitted to a normality test and variance analysis was compared using orthogonal contrasts (linear, quadratic, and quadratic deviation) with a significance level of 5\% according to PROC GLM. Following contrast analysis, when it was statistically significant, 
regression equation parameters were determined using PROC REG.

\section{Results and Discussion}

In the evaluation of the effect of biofertilizers on the vegetative development of Cenchrus ciliares, improved morphogenic responses were observed from the $2^{\text {nd }}$ vegetative cycle, with only the variables LLt for the CB (Figure 1A) and L/S ratio for the OB (Figure 1B), indicating a significant effect during the $1^{\text {st }}$ cycle. For these variables, it was possible to observe a significant effect regarding the dose levels.

Figure 1. Effect of the use of two biofertilizers (derived from goat and sheep feces) at five doses $(0 \%, 2.5 \%, 5.0 \%$, $7.5 \%$, and $10 \%$ of soil volume) during the first vegetative cycle of buffel grass, on A - total leaf lifespan duration (LLt (days)) and $\mathrm{B}$ - leaf/stem ratio (L/S ratio).

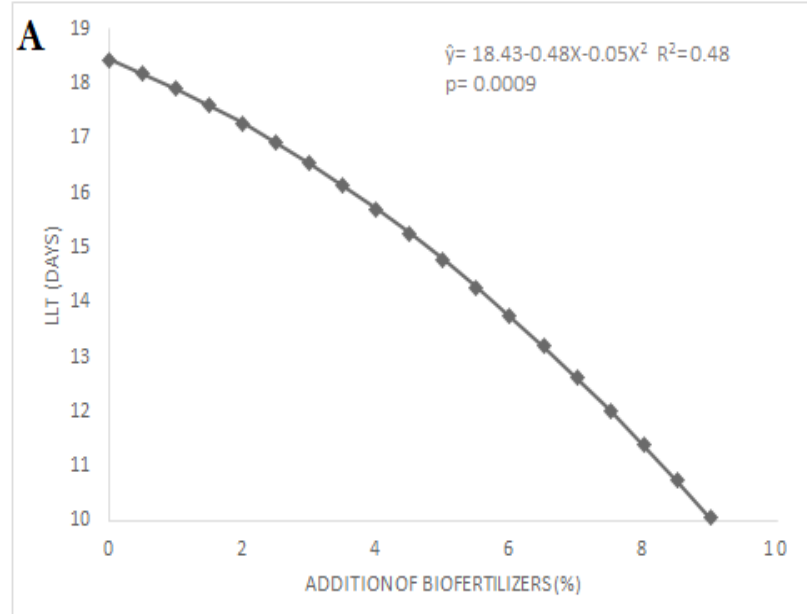

Thus, it can be determined that the potential effect of both biofertilizers was more evident from the second application of the various doses, probably due to the adequate soil fertility conditions created by the fertilization, as exemplified by the levels of $\mathrm{P}$ which practically doubled in concentration from the $1^{\text {st }}$ to the $2^{\text {nd }}$ cycle in the various doses tested, which is greatly relevant, especially for initial development of the plants (Table 1). According to VarinderpalSingh et al. (2006), organic fertilization, such as that resulting from the use of biofertilizers, has the potential to release soluble $\mathrm{P}$ in the soil.

When analyzing the effect of the biofertilizers on each morphogenic variable assessed, an elevated LSR was observed, demonstrating that the use of biofertilizers can result in an increased forage yield. A quadratic effect was observed regarding the doses

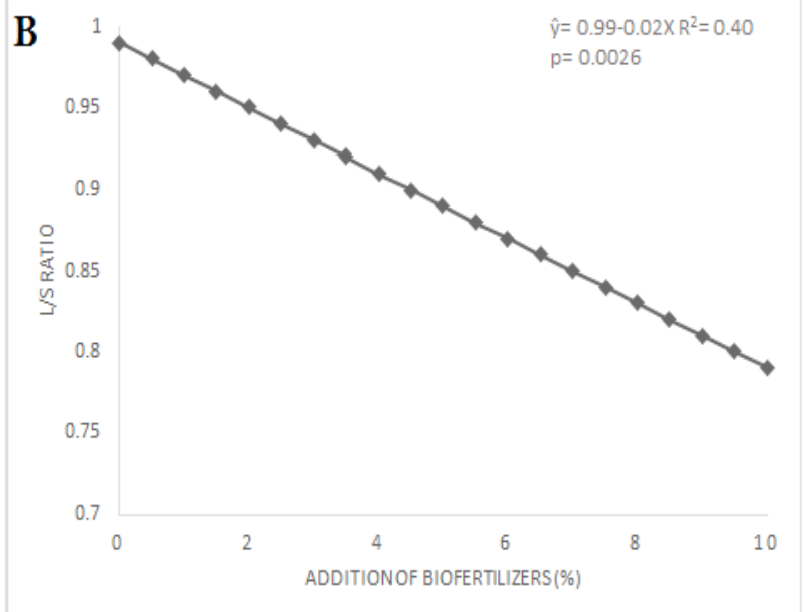

applied, and by using a derivation of the equation $\left[\hat{y}=0.30+0.03 X-0.002 X\right.$ with $\left.R^{2}=0.72\right]$, it was found that the maximum rate of 0.41 leaves/tiller/ day was obtained at the dose of $7.5 \%$ (Figure 2A). Vasconcelos et al. (2013) also found significant differences regarding the LSR while evaluating morphogenic characteristics of buffel grass fertilized using solid bovine digesta, with improved responses in the third cut. In a study on the application of pig liquid excreta in millet culture by Mondardo et al. (2011), in which six doses were evaluated $(0,23$, $46,69,92$, and $\left.115 \mathrm{~m}^{3} \mathrm{ha}^{-1}\right)$, the best responses regarding TApF $(\mathrm{P}<0.05)$ were found at the dose of $61 \mathrm{~m}^{3} \mathrm{ha}^{-1}$. These results differ from Edvan et al. (2010), who found no difference $(P>0.10)$ for the LSR while evaluating the use of organic fertilization (bovine digesta and excreta) on buffel grass pastures (Cenchrus ciliaris var. molopo). 
Regarding the variables LER and PsER, a quadratic effect was also observed for the doses, with the $8.4 \%$ dose resulting in increased leaf elongation, with a maximum growth rate of 90 $\mathrm{mm} /$ leaf/day, leading to an approximate increase of $44.7 \%$ compared to the control (Figure 2B). Regarding the PsER, $13.72 \mathrm{~mm} /$ day was the minimum value estimated, with the use of $7.3 \%$ biofertilizer, and with an increase of $59 \%$ resulting from the derivation of the equation $[\hat{y}$ $=5.80+2.18 \mathrm{X}-0.15 \mathrm{X}^{2}$ with $\mathrm{R}^{2}=0.56$ ] (Figure $2 \mathrm{C})$. Pseudostem elongation is directly related to leaf sprouting and the final length of the leaf blade, whereby the longer the stem, the greater the distance that must be covered by the leaf, and consequently the greater its final length (PONTES et al., 2003), which justifies the effect of the fertilizer doses regarding both variables.

Figure 2. Effect of the use of two biofertilizers (derived from goat and sheep feces) at five doses $(0 \%, 2.5 \%, 5.0 \%$, $7.5 \%$, and $10 \%$ of soil volume) during the second vegetative cycle of buffel grass, on A - leaf sprouting rate [LSR (leaf/ tiller/day)], B - leaf elongation rate [LER (mm/leaf/day)], C - pseudostem elongation rate [PsER (mm/leaf/day)], and D - senescence rate $[\mathrm{SnR}$ (mm/leaf/day)].

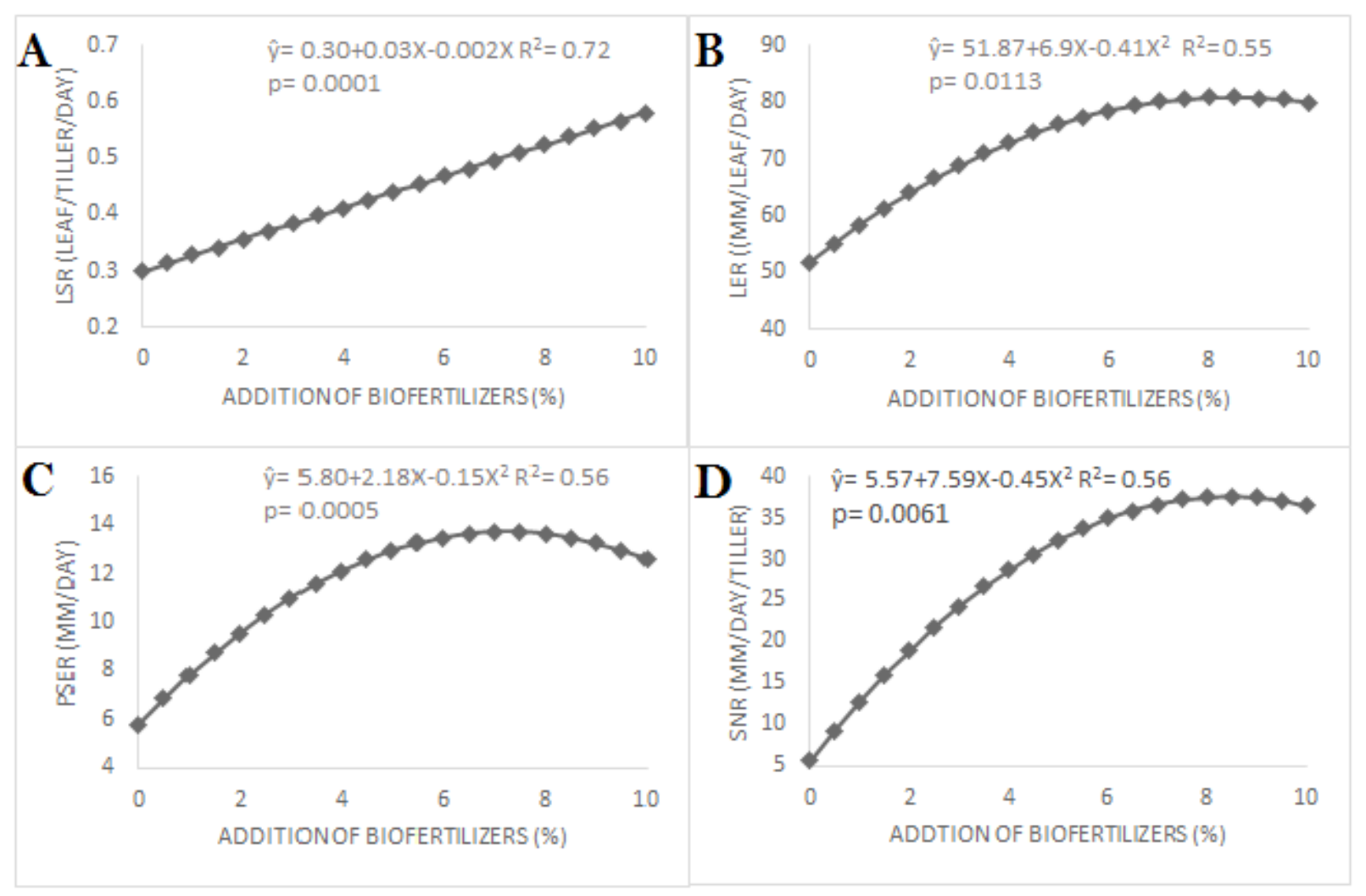

Elongation rates are mainly influenced by the levels of nitrogen and, in the present study, an average of $13.5 \mathrm{~g} \mathrm{~kg}^{-1}$ of soil was obtained at the doses of $7.5 \%$ to $10 \%$ of both biofertilizers (Table 1). Previous studies showed that it is possible to verify that doses lower than $7.5 \%$ to $10 \%$ already have an effect; Mondardo et al. (2011) who found a significant effect of those variables on millet cultivation when using pig liquid excreta containing on average $2.63 \mathrm{~g} \mathrm{~N} \mathrm{~kg}^{-1}$. Similarly, nitrogen fertilization $\left(1.2 \mathrm{~g} \mathrm{~kg}^{-1}\right)$ led to an LER and PsER increase of $21.68 \%$ and $31 \%$, respectively, on buffel 
grass cultivars (PORTO et al., 2014). However, the addition of doses of nitrogen higher than $615.6 \mathrm{~kg} \mathrm{ha}^{-1}$ per year can reduce the LER and PsER, as observed in andropogon grass plants (MAGALHÃES et al., 2013).

Regarding the SnR, a quadratic effect was observed for the various doses, with a minimum senescence of $37.5 \mathrm{~mm} /$ day/tiller obtained with the use of $8.4 \%$ of both fertilizers (Figure 2D). These values are lower than those found by Moreira et al. (2015) for the same cultivar of buffel grass, with a SnR of $127 \mathrm{~mm}$ day $^{-1}$, likely due to the plants being evaluated for a longer period in the present study (70 days).

The handling method used in that study resulted in an elevated senescence rate, a natural process that occurs due to ageing of the plants and during their functional processes (respiration and transpiration) (NABINGER, 1996); however, increased senescence rates are justified by the increase in plant growth, as observed in the LER, which was also improved at a dose of $8.4 \%$. In a pasture, one of the phenomena that can lead to the loss of an important amount of biomass during harvest is leaf and stem senescence (NABINGER, 1996).

Regarding the variable LLt, an interaction effect was observed between the biofertilizers and doses in both cycles tested, with the use of $4.8 \%$ of $\mathrm{CB}$ in the first cycle, allowing a maximum of 15 days of LLt (Figure 1A), whereas in the $2^{\text {nd }}$ cycle, the maximum estimated value was 13.6 days, with $9 \%$ OB (Figure 3).

Figure 3: Total leaf lifespan (LLt (days)) of buffel grass cultivated with five doses $(0 \%, 2.5 \%, 5.0 \%, 7.5 \%$, and $10 \%$ of soil volume) of two biofertilizers (derived from goat and sheep feces) during the second vegetative cycle.

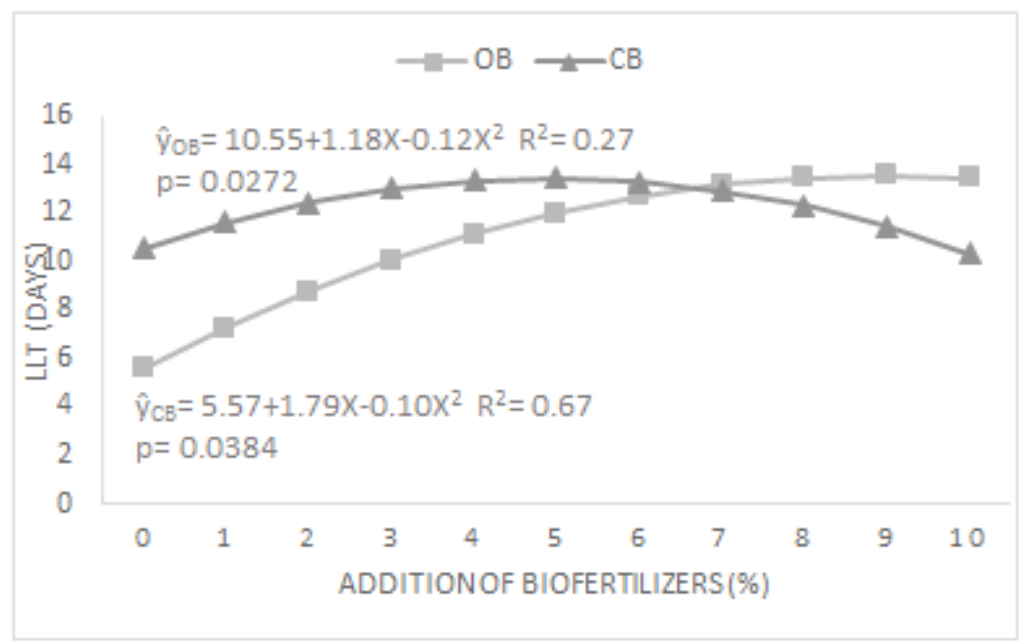

LL results from the equilibrium between growth and senescence, since the leaves have a limited lifespan determined by genetic characteristics and influenced by environmental factors (NABINGER, 1996). OB was remarkable regarding this variable, which allowed greater fluxes of leaf growth and lifespan, characteristics that are determined by
NPK levels in the soil, with N mainly impacting on the expression of morphogenic variables leading to an increase in LER, and with $\mathrm{K}$ increasing the leaf length (LL) (HODGSON, 1990).

Moreira et al. (2015) found a mean LL of 17.53 days, while evaluating the morphogenic characteristics of six buffel grass accessions in a 
period of 70 days. The lower LL found in the present study is also associated with the shorter evaluation period, considering 30\% inflorescence.

With respect to structural characteristics, for the variable LW-Expd there was significant interaction between biofertilizers and doses, allowing the regression adjustment to be performed according to the linear model $\hat{y}=0.48+0.01 X$ with $\left.R^{2}=0.52\right]$ for $\mathrm{OB}$ and the quadratic model $[\hat{\mathrm{y}}=0.43+0.04 \mathrm{X}$ - $0.003 \mathrm{X}^{2}$ with $\mathrm{R}^{2}=0.70$ ] for $\mathrm{CB}$, with a maximum of $0.58 \mathrm{~cm}$ at the dose of $7.5 \% \mathrm{OB}$, whereas for the dose of $6.6 \% \mathrm{CB}$, there was a minimum estimate value of $0.56 \mathrm{~cm}$, with an increase of $19 \%$ and $30 \%$, respectively, compared to the control (Figure 4). These values are close to the buffel grass foliar blade mean width of $0.63 \mathrm{~cm}$ found by Silva et al. (2011).

Figure 4. Width of the expanded leaf (LW-Expd $(\mathrm{cm}))$ of buffel grass cultivated with five doses $(0 \%, 2.5 \%$, $5.0 \%, 7.5 \%$, and $10 \%$ of soil volume) of two biofertilizers (derived from goat and sheep feces) during the second vegetative cycle.

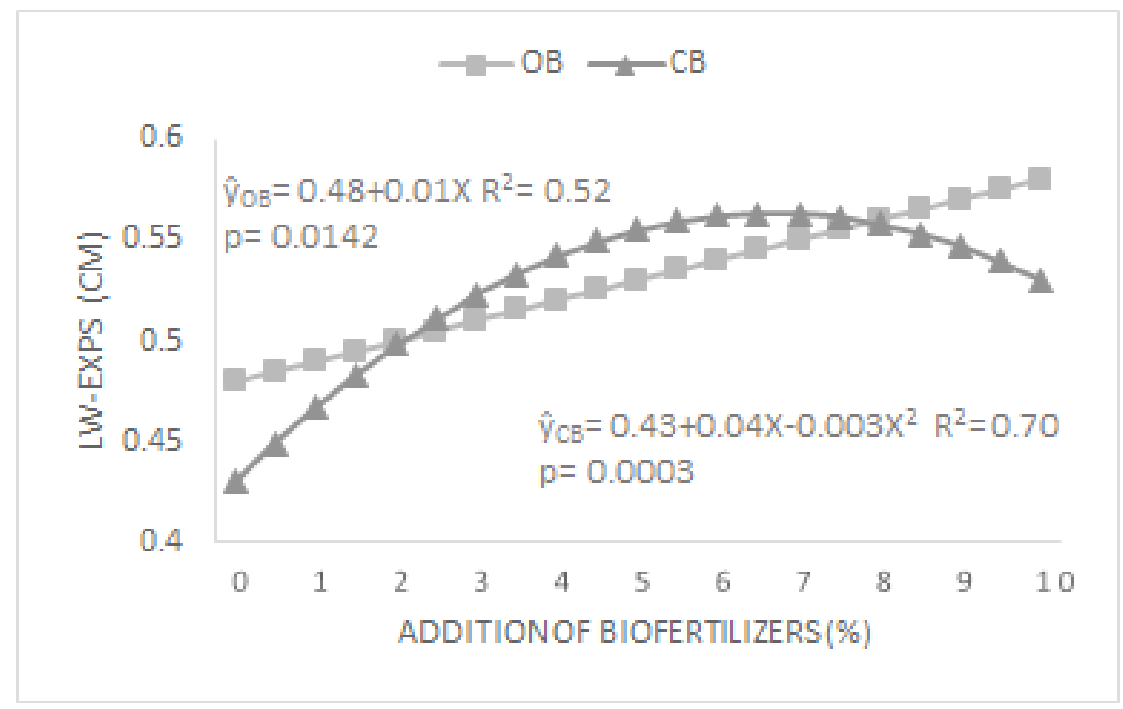

Leaf length and width are decisive factors in the establishment of leaf area, permitting greater light interception and consequently, increased photosynthetic rates. According with Andrade et al. (2005), leaf area is an extremely important factor among the variables related to plant growth and production, as $90 \%$ of the plant's dry matter weight is due to photosynthetic carbon assimilation.

For the NLEmerg, a quadratic effect was observed in the dose levels, with no interaction between the biofertilizers that showed an estimated minimum of $9.4 \mathrm{~cm}$ at the dose of $8.7 \%$, with an increase of $33.6 \%$ compared to the control dose (Figure 5B). In the NLExpd there was an interaction effect between biofertilizers and doses, with a greater effect at $10 \%$ reaching a $50 \%$ increase when compared to dose 0 (Figure 5A). There was no significant effect on the NLExps in both cycles. As such, the ratio LExpd/LExps behaved in a linear way, with better performance at the $10 \%$ doses for both biofertilizers, with the increase in number of expanded leaves with higher levels of biofertilizers.

Regarding the NLL, in the $2^{\text {nd }}$ cycle a quadratic effect was observed for dose levels, with a minimum estimated value of 8.03 leaves per tiller at the dose of $10 \%$ (Figure 5C). The effect of using higher doses of fertilizers on NLL is reinforced by the response of the buffel grass regarding the morphogenic traits 
LER and LL observed in this study.

Higher doses of biofertilizer resulted in the increase in NLEmerg, NLExpd, and NLL per tiller of buffel grass. The number of leaves contributes to biomass accumulation in pastures, as they intercept a great amount of light energy and represent a substantial part of the active photosynthetic tissue, guaranteeing the plant's production of photoassimilates, and thus constitute a material of high nutritional value for ruminants (ALEXANDRINO et al., 2004).

Cunha et al. (2011) evaluated the effects of different doses of nitrogen and potassium fertilizer on xaraes palisadegrass (Brachiaria brizantha) and found that the increase in dose of fertilizers lead to a linear increase in NLExpd and NLL, with no effect on NLEmerg. In the present study, it was observed that, in general, biofertilizers increased the levels of soil $\mathrm{N}$, P, and $\mathrm{K}$, in addition to the levels of organic matter (data not shown) when compared to control soil (dose 0 of biofertilizer) (Table 1), resulting in an increase in the observed NLEmerg, NLExpd, and NLL in this study. Conversely, Fagundes et al. (2006) found no effect of the use of $\mathrm{N}$ on these variables in brachiaria grass, indicating that soil elements, and other aspects related to handling, can influence the plant's responses.

Figure 5. Effect of the use of two biofertilizers (derived from goat and sheep feces) at five doses $(0 \%, 2.5 \%, 5.0 \%$, $7.5 \%$, and $10 \%$ of soil volume) during the second vegetative cycle of buffel grass, on A - number of expanded leaves (leaf/tiller), B - number of sprouted leaves [NLEmerg $(\mathrm{cm})$ ], and C - number of live leaves (leaf/tiller).

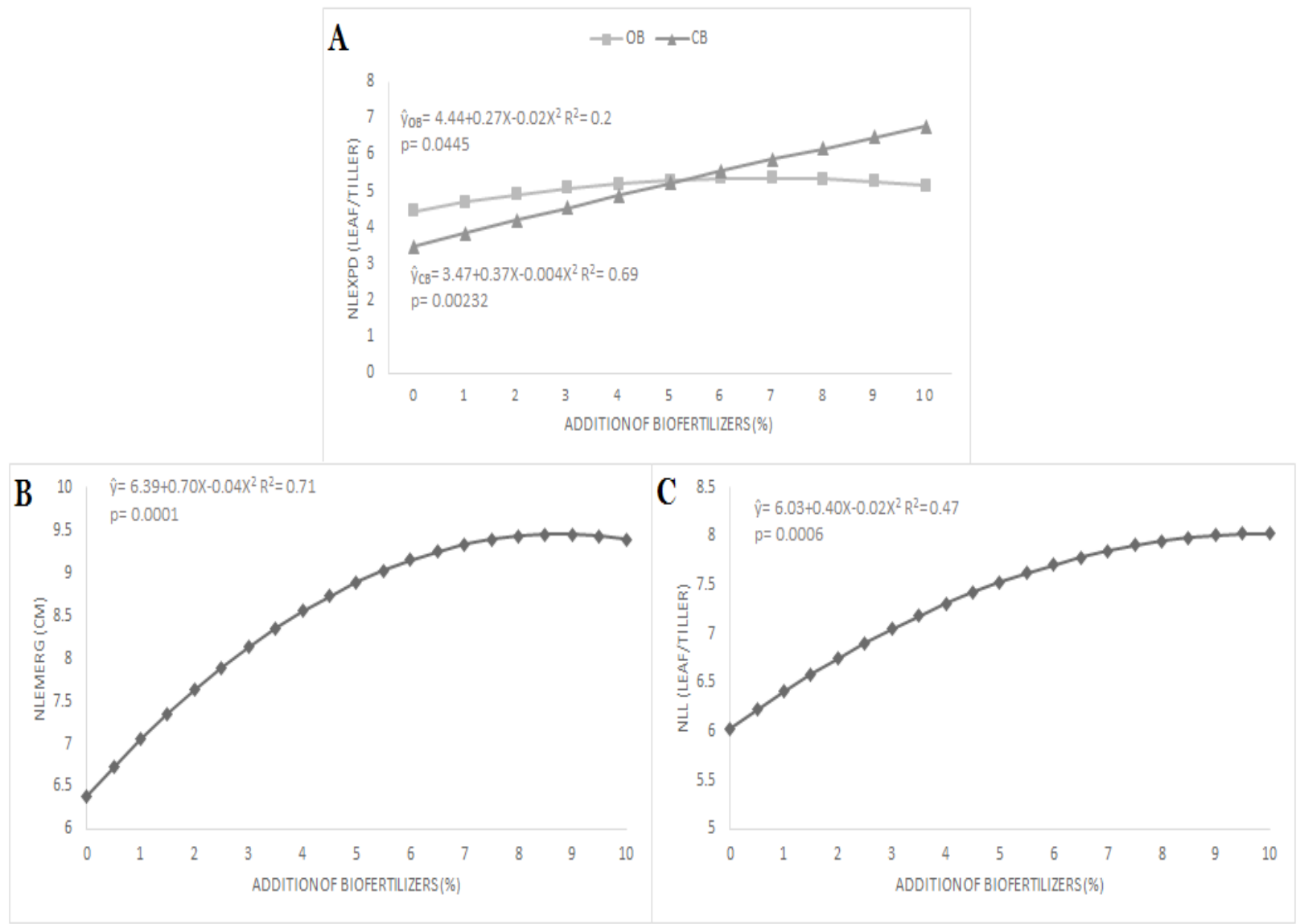


Regarding L/S ratio, an interaction effect between biofertilizers and dose levels was observed in the $1^{\text {st }}$ cycle (Figure 1B). At dose 0, there was a higher L/S ratio compared to other levels of $\mathrm{OB}$. In the $2^{\text {nd }}$ cycle, there was a dose effect corresponding to a linear equation, whereby dose 0 resulted in higher L/S ratio with both fertilizers (Figure 6). These results can be due to an increase in buffel grass growth rate due to the use of biofertilizers, and the consequent increase in PsER. The accumulation of stem in the forage sward is usually undesirable, representing a large energy demand for the growth of that fraction, and negatively impacting the nutritional value of the forage produced (DIFANTE et al., 2009). Different results were obtained by Edvan et al. (2010), who did not observe a significant difference regarding $\mathrm{L} / \mathrm{S}$ ratio $(\mathrm{P}>0.10)$, when evaluating the use of organic fertilizers (bovine digesta and excreta) on buffel grass pastures (Cenchrus ciliaris var. molopo).

Figure 6. Leaf/stem ratio (L/S ratio) of buffel grass cultivated with five doses $(0 \%, 2.5 \%, 5.0 \%, 7.5 \%$, and $10 \%$ of soil volume) of two biofertilizers (derived from goat and sheep feces) during the second vegetative cycle.

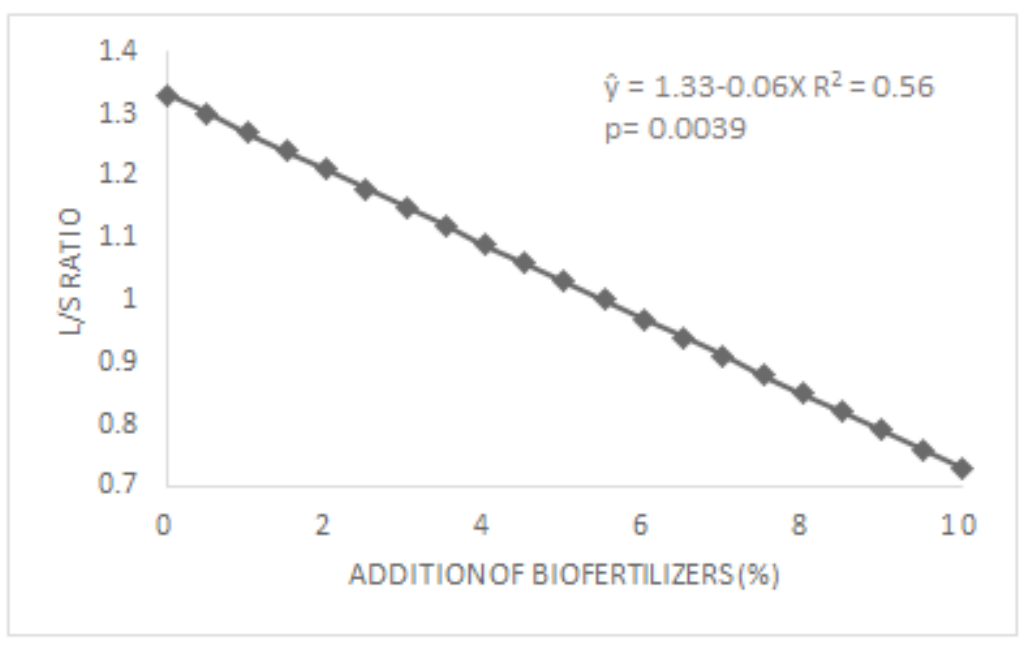

Regarding the production of total dry biomass, an effect of the dose levels was observed for OB in the first vegetative cycle and an interaction between dose and fertilizer in the second cycle, thus allowing the following linear regression adjustment $\left[\hat{y}=4.86+0.19 X\right.$ with $\left.R^{2}=0.67\right]$ for $\mathrm{OB}$ in the first cycle, with a maximum production of $6.8 \mathrm{~g}$ of dry matter (DM) per pot with $10 \% \mathrm{OB}$; a $30 \%$ increase when compared to dose 0 (Figure 7A). A linear behavior was observed in the second cycle for the $\mathrm{OB}\left[\hat{\mathrm{y}}=1.37+0.52 \mathrm{X}\right.$ with $\left.\mathrm{R}^{2}=0.96\right]$ and quadratic for the $\mathrm{CB}\left[\hat{\mathrm{y}}=1.83+0.84 \mathrm{X}-0.02 \mathrm{X}^{2}\right.$ with $\mathrm{R}^{2}=0.97$ ], with production peaks of 7.16 and $7.74 \mathrm{~g} /$ pot, respectively, an increase in $73 \%$ in relation to the control at the dose of $10 \%$ for both fertilizers (Figure 7B). The quadratic behavior observed in the total dry biomass with the use of caprine biofertilizer may be due to the increase in the soil's electric conductivity (data not shown), suggesting that the choice of type of fertilizer must be carefully assessed. It is worth noting that $10 \%$ of each biofertilizer would correspond to 200 ton $\mathrm{ha}^{-1}$; considering that they comprise approximately $4 \%$ of total solids, the estimated value would be 8 ton $\mathrm{ha}^{-1}$ of fertilizer produced from animal feces. Thus, this technology would aid in fertilization of soils in semi-arid regions and decrease the use of irrigation for the production of forage. 
Figure 7. Biomass of buffel grass cultivated with five doses $(0 \%, 2.5 \%, 5.0 \%, 7.5 \%$, and $10 \%$ of soil volume) of two biofertilizers (derived from goat and sheep feces) during A - the first vegetative cycle, and B - the second vegetative cycle.
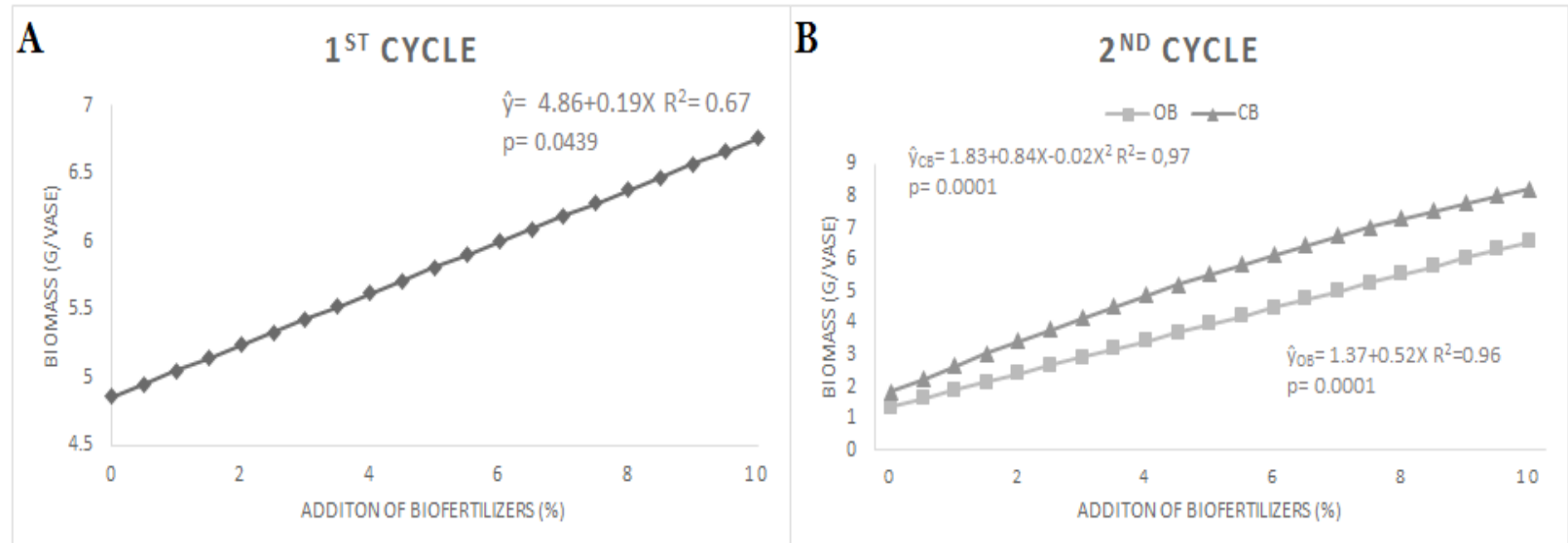

The morphogenic and structural characteristics observed, namely regarding LSR, LER, PsER, LL and LLgt-Expd, which performed better with the increase in dose of biofertilizer used, were reflected in biomass production, showing an important increase in production and productivity of buffel grass, resulting in an increased forage yield.

These results are consistent with those of Quadros et al. (2010), who evaluated the effect of biofertilizers derived from the anaerobic biodigestion of goat and sheep excreta and observed that elephant grass harvested from areas that received the biofertilizer, presented a $24 \%$ and $15 \%$ increase in green matter and DM compared to controls that were not fertilized, with differences corresponding to 6.6 and $0.6 \mathrm{t} \mathrm{ha}^{-1}$, respectively. Blank et al. (2007) also observed an increase in lemon grass biomass (Cymbopogon citratus (D.C.) Stapf) with the use of higher doses of Vitasolo commercial biofertilizer. Similarly, Brachiaria brizhanta var. marandú grass also showed a significant increase in forage mass productivity with the increase in doses of chicken manure (SILVA et al., 2013). Several authors have demonstrated that the use of biofertilizers leads to an increase in grass forage mass for animals.

\section{Conclusion}

Biofertilizers that originate from the anaerobic biodigestion of goat and sheep feces increase the main morphogenic and structural characteristics of buffel grass (Cenchrus ciliaris), resulting in an increased production of forage mass for animals.

\section{Acknowledgements}

To CAPES from granting the scholarship to the first author, to the CNPq for the PQ (AMYM) and IC (ACH) scholarship, to Facepe (APQ-1265-2.03/10) for the financial support, to Embrapa Semiárido and the Universidade Federal do Vale do São Francisco for the support and use of infrastructure.

\section{References}

ALEXANDRINO, E.; NASCIMENTO JÚNIOR, D.; MOSQUIM, P. R. Características morfogênicas e estruturais na rebrotação da Brachiaria brizantha cv. Marandu submetida a três doses de nitrogênio. Revista Brasileira de Zootecnia, Brasília, v. 26, n. 6, p. 13721379, 2004.

ANDRADE, A. C.; FONSECA, D. M.; LOPES, R. S.; NASCIMENTO JÚNIOR, D.; CECON, P. R.; QUEIROZ, D. S.; PEREIRA, D. H.; REIS, S. T. Analise de crescimento do capim-elefante Napier adubado e irrigado. Ciência Agrotecnica, Lavras, v. 29, n. 2, p. 415-423, 2005. 
BLANK, A. F.; ARRIGONI-BLANK, M. F.; AMANCIO, V. F.; MENDONÇA, M. C.; SANTANA FILHO, L. G. M. Densidades de plantio e doses de biofertilizante na produção de capim-limão. Horticultura Brasileira, Botucatu, v. 25, n. 3, p. 343-349, 2007.

CUNHA, F. F.; RAMOS, M. M.; ALENCAR, C. A. B.; OLIVEIRA, R. A.; ARAÚJO, R. A. S.; CECON, P. R.; MARTINS, C. E.; CÓSER, A. C. Número de folhas do capim-xaraés em diferentes manejos e doses de adubação, intervalos de desfolha e estações anuais. Bioscience Journal, Uberlândia, v. 27, n. 2, p. 271-282, 2011.

DIFANTE, G. S.; EUCLIDES, V. P. B.; NASCIMENTO JÚNIOR, D. Ingestive behavior, herbage intake and grazing efficiency of beef cattle steers on Tanzania guineagrass subjected to rotational stocking managements. Revista Brasileira de Zootecnia, Viçosa, MG, v. 38, n. 6, p. 1001-1008, 2009.

EDVAN, R. L.; SANTOS, E. M.; VASCONCELOS, W. A.; SOUTO FILHO, L. T.; BORBUREMA, J. B.; MEDEIROS, G. R.; ANDRADE, A. P. Utilização de adubação orgânica em pastagem de capim-buffel (Cenchrus ciliaris cv. Molopo). Archivos de Zootecnia, Córdoba, v. 59, n. 228, p. 499-508, 2010.

EGLER, M.; EGLER, C. A. G.; FRANZ, B.; ARAUJO, M. S. M. de; FREITAS, M. A. V. de. Indicators of deforestation in the Southern Brazilian Pre-Amazon. Regional Environmental Change, New York, v. 13, n. 2, p. 263-271, 2013.

FAGUNDES, J. L.; FAGUNDES, J. L.; FONSECA, D. M.; MISTURA, C.; MORAIS, R. V.; VITOR, C. M. T.; GOMIDE, J. A.; NASCIMENTO JUNIOR, D. D. R. C.; COSTA, L. T. Características morfogênicas e estruturais do capim-braquiária em pastagem adubada com nitrogênio avaliadas nas quatro estações do ano. Revista Brasileira de Zootecinia, Viçosa, MG, v. 35, n. 1, p. 21-29, 2006.

HODGSON, J. Grazing management: science into practice. London: Longman Scientific and Technical, Longman Group, 1990. 203 p.

INSTITUTO BRASILEIRO DE GEOGRAFIA E ESTATÍSTICA - IBGE. Produção da Pecuária Municipal, Rio de Janeiro, v. 40, n. 1, p. 1-68, 2012.

LOURENTE, E. R. P.; MERCANTE, F. M.; ALOVISI, A. M. T.; GOMES, C. F.; GASPARINI, A. S.; NUNES, C. M. Atributos microbiológicos, químicos e físicos de solo sob diferentes sistemas de manejo e condições de cerrado. Pesquisa Agropecuária Tropical, Goiânia, v. 41, n. 1, p. 20-28, 2011.
MAGALHÃES， J. A.; CARNEIRO, M. S. S.; ANDRADE, A. C.; PEREIRA, E. S.; ANDRADE, A. P.; BAKKE, O. A.; RODRIGUES, B. H. N.; FILHO, W. J. E. M.; COSTA, N. L. Características morfogênicas e estruturais do capim-andropogon sob irrigação e adubação. Semina: Ciências Agrárias, Londrina, v. 34, n. 5, p. 2427-2436, 2013.

MONDARDO, D.; BELLON, P. P.; MEINERZ, C. C.; CASTAGNARA, D. D.; SANTOS, L. B.; OLIVEIRA, P. S. R.; MESQUITA, E. E. Aplicação de dejeto líquido suíno na cultura do milheto. Ensaios e Ciência: Ciências Biológicas, Agrárias e da Saúde, Valinhos, v. 15, n. 2, p. 87-100, 2011.

MOREIRA, J. A. S. ; FAGUNDES, J. L.; MISTURA, C.; LEMOS, N. L. S.; MOREIRA, J. N.; BACKES, A. A.; MORAIS, J. A. S.; OLIVEIRA, V. S.; MOREIRA, A. L. Características morfogênicas, estruturais e produtivas de acessos de capim-buffel. Semina: Ciências Agrárias, Londrina, v. 36, n. 1, p. 391-400, 2015.

NABINGER, C. Aspectos ecofisiológicos do manejo de pastagens e utilização de modelos como ferramenta de diagnóstico e indicação de necessidades de pesquisa. In: REUNIÃO DO GRUPO TÉCNICO REGIONAL DO CONE SUL (ZONA CAMPOS) EM MELHORAMENTO E UTILIZAÇÃO DE RECURSOS FORRAGEIROS DAS ÁREAS TROPICAL E SUBTROPICAL, 1996, Porto Alegre. Anais... Porto Alegre: Universidade Federal do Rio Grande do Sul, 1996. p. 18-56.

NAWAZISH, S.; HAMEED, M. S. N. Leaf anatomical adaptations of Cenchrus ciliaris L. from the salt range, pakistan against drought stress. Pakistan Journal of Botany, Karachi, v. 38, n. 5, p. 1723-1730, 2006.

PEREIRA, V. V. The importance of morphogenic characteristics on the tissue flow in the management of tropical pastures. Revista em Agronegócios e Meio Ambiente, Maringá, v. 6, n. 2, p. 289-309, 2013.

PONTES, L. S.; NABINGER, C.; CARVALHO, P. C. F.; TRINDADE, J. K.; MONTARDO, D. P.; SANTOS, R. J. Variáveis morfogênicas e estruturais de azevém anual (Lolium multiflorumLam.) manejado em diferentes alturas. Revista Brasileira de Zootecnia, Viçosa, MG, v. 32, n. 4, p. 814-820, 2003.

PORTO, E. M. V.; VITOR, C. M. T.; ALVES, D. D.; LIMA, M. V. G.; SILVA. M. F. Características morfogênicas de cultivares do capim buffel submetidos à adubação nitrogenada. Agropecuária Científica no Semi-Árido, Campina Grande, v. 10, n. 1, p. 14-21, 2014. 
QUADROS, D. G.; OLIVER, A. P. M.; REGIS, U.; VALLADARES, R.; SOUZA, P. H. F.; FERREIRA, E. J. Biodigestão anaeróbia de dejetos de caprinos e ovinos em reator contínuo de PVC flexível. Revista Brasileira de Engenharia Agrícola e Ambiental, Campina Grande, v. 14 , n. 3, p. 326-332, 2010.

SILVA, A. A.; SIMIONI, G. F.; LUCENA, A. Efeito da adubação orgânica no crescimento do capim Brachiaria brizantha cv. Marandu em Parecis/Rondônia. Enciclopédia Biosfera, Goiânia, v. 9, n. 16, p. 923-932, 2013.

SILVA, E. B.; CARNEIRO, M. S. S.; EDVAN, R. L.; COUTINHO, M. J. F.; RODRIGUES JÚNIOR, C. T.; SILVA, M. S. M. Componentes morfológicos e curva de desidratação de gramíneas tropicais. Tecnologia e Ciência Agropecuária, João Pessoa, v. 5, n. 3, p. 43-46, 2011.
SILVA, J. G.; NASCIMENTO, J. M. L.; SANTOS, M. R. B.; GAMA, A. A.; QUEIROZ, M. A. A.; YANO-MELO, A. M. Biofertilizante caprino no desenvolvimento de Urochloa ruziziensis. Archivos de Zootecnia, Córdoba, v. 64, n. 248, p. 323-329, 2015.

VARINDERPAL-SINGH; DHILLON, N. S.; BRAR, B. $\mathrm{S}$. Effect of incorporation of crop residues and organic manures on adsorption/desorption and bio-availability of phosphate. Nutrient Cycling in Agroecosystems, Ithaca, v. 76, n. 1, p. 95-108, 2006.

VASCONCELOS, W. A.; ANDRADE, A. P.; SANTOS, E. M.; EDVAN, R. L.; SILVA, D. S.; SILVA, T. C. Características morfogenéticas e produção do capim buffel adubado com digesta bovina sólida. Revista Brasileira de Saúde e Produção Animal, Salvador, v. 14, n. 1, p. 1-9, 2013. 
